\title{
Az ERGO hangsúlya a Családok Évében: a kötődés éltető erő
}

\author{
The emphasis of ERGO Organization in the Year of the Family: \\ bonding is a life-giving force
}

\author{
Szerzők: Ékes Ilona $\bowtie$, Varga Gabriella \\ ERGO - Európai Regionális Szervezet
}

Beküldve: 2018. 10. 19.

doi: $10.24365 /$ ef.v59i5.366

Kulcsszavak: ergo; creighton; teenstar; szülés; szoptatás; családok éve

Keywords: ergo; creighton; teenstar, birth; breastfeeding; year of the family

Családban élni jó, szülőnek, nagyszülőnek lenni jó, a gyermek jövetele az anyának, az apának és a társadalomnak egyaránt áldás - de hogy ez valóban így legyen, azért tennünk, dolgoznunk kell: hozzá kell segítenünk önmagunkat és egymást a biztonsághoz, kiegyensúlyozottsághoz, egészséghez és boldogsághoz, az élet egészéhez nélkülözhetetlen kötődések kialakulásához, megerősítéséhez. Erre hívta fel a figyelmet 2018-ban, a Családok Évében és a Külhoni Magyar Családok Évében konferencia-, illetve pódiumbeszélgetéssorozatával az ERGO - Európai Regionális Szervezet, és nemcsak felhívta a figyelmet, hanem segítséget is nyújtott ehhez: a TeenSTAR nemzetközi szexuálpedagógiai személyiségfejlesztő program, a természetes családtervezést segítő Creighton Model Módszer és NaProTechnológia megismertetésével, valamint a háborítatlan szülés, szoptatás és az ennek révén kialakuló kötődés fontosságának hangsúlyozásával.

A tizenegy éves múltú, budapesti székhelyű ERGO Európai Regionális Szervezet 2018-ban, az Emberi Erőforrások Minisztériuma által meghirdetett Családok Évében és a Nemzetpolitikai Államtitkárság által ehhez kapcsolt Külhoni Magyar Családok Évében kiteljesítette az elmúlt évekből Áldás, népesség néven ismertté vált programját, mely azon alapszik, hogy a lelki szükségletet jelentő kötődések alapfeltételei a gyermek boldogságra képes, egészséges fiatallá, majd felnőtté válásának.
Az egészséges kötődéskialakulás érdekében fontosnak tartjuk már serdülőkorban megkezdeni a szülővé válásra való felkészítést, ehhez kapcsoljuk a természetes családtervezést, majd a háborítatlan szülés és szoptatás fontosságát. Ezt a folyamatot tartjuk a kötődéskialakulás alapjának. Kötődésre pedig azért van szükségünk, mert e nélkül nem lehet élni. Ez adja a biztonságot az életben, ez tesz képessé a kiegyensúlyozottságra. A kötődés épp olyan szükséglete a léleknek, mint a testnek az élelem, a víz vagy a levegő. Ennek a kérdéskörnek a gyökereit taglalta Kötődés - az Éltető Erő címú konferenciasorozatunk az év első felében Szolnokon, Miskolcon, Egerben, Békéscsabán és Budapesten, az év második felében pedig a Kárpát-medence különböző területein, elsőként Székelyföldön.

\section{TEENSTAR - ÚT AZ ÖNMEGISMERÉS FELÉ}

Szervezetünk 2016 óta dolgozik azon, hogy az ifjúság egészségmegőrzése terén jelentős eredményeket elért, a világ számos országában sikeres, a szülők és a diákok körében egyaránt nagy népszerüségnek örvendő TeenSTAR nemzetközi személyiségfejlesztő szexuálpedagógiai program tananyaga itthon is elérhetővé váljék, és a képzéshez a Kárpátmedence magyar fiataljai is hozzáférjenek. A TeenSTAR válaszokat ad a fiatalok kérdéseire, 
családi kereteken kívül. Ahhoz nyújt segítséget, hogy kiskamaszkorban az identitás férfiként és nőként kibontakozzon, szilárddá, stabillá váljon; támogatja a fiatalokat abban, hogy egészségesen tudjanak kötődni saját testükhöz és egymáshoz, valamint egészségesen viszonyuljanak saját termékenységükhöz. A képzés nemcsak a biológiai, hanem a lelki vonatkozásokat is tárgyalja, azt, hogy serdülőkorban miként változik a szervezet, az érzelmi világ és hogyan alakul ki, erősödik meg az értékrend. Rendkívül sokat segít a fiataloknak a szülőségre való felkészülésben. Segít nekik megérteni a pubertás idején a testükben és a lelkükben lejátszódó változásokat, segít azokat a kialakuló identitásukba, valamint a szexualitást a személyiségükbe integrálni. A TeenSTAR holisztikus szemlélettel közelíti meg a szexualitás és a nemi identitás kérdését, miközben érintetlenül hagyja a biológiai és a társadalmi nem közötti kapcsolatot. Pozitív attitűdöt alakít ki az iránt, hogy az ember nőnek és férfinak született. A szexualitást a testi, lelki, szellemi hatások egységeként közelíti meg. S mivel a pozitív testképen és a termékenységünk nagyra értékelésén alapul, ezért az érési folyamatot lépésenként, az életkornak megfelelően teszi érthetővé. Így jutnak el a fiatalok az érett, megalapozott, a biológiai nemükkel összhangban álló nemi identitásukhoz és készülnek fel a felelősségteljes szexuális életre. A program segíti őket abban is, hogy ellenálljanak a kortársak és a média nyomásának. A képzés nyílt légköre hozzájárul a szülők és gyermekeik közötti párbeszéd elősegítéséhez is.

\section{CREIGHTON MODEL MÓDSZER ÉS NAPROTECHNOLÓGIA}

A Creighton Model FertilityCare ${ }^{\mathrm{TM}}$ módszer olyan családtervezési rendszer, amelynek segítségével természetes módon válik lehetővé a várandósság elérése vagy elkerülése, anélkül, hogy a nő termékenységét elfojtaná, reproduktív rendszerét károsítaná. A női ciklus megismerésének, feltérképezésének a módszere. Tanulása hozzásegít ahhoz, hogy felismerjük és átlássuk a női ciklus során bekövetkező változásokat, megkülönböztessük a termékeny és terméketlen időszakokat. E mellett képesek leszünk saját egészségünk nyomon követésére és megőrzésére egész fogamzásképes életszakaszunk során. A Creighton Model módszer a termékenységet egészségünk részének tekinti, és nem múltbeli ciklusaink történéseire hagyatkozik, hanem napról napra információt nyújt termékenységünkkel kapcsolatosan. Megtanít testünk jelzéseinek figyelésére, termékenységünk nagyrabecsülésére. Számos előnye van: egyénre szabott, orvosilag biztonságos, erkölcsileg elfogadható, könnyû megtanulni, olcsóbb, mint más fogamzásgátló módszerek, megbízható, természetes és a női ciklushoz igazodik. Közös felelősségen alapul, tiszteletben tartja a nő méltóságát, segít a házastársi kötelékek megerősítésében. Sokoldalú, precíz. Értékes segítség és kiemelkedően eredményes meddőséggel küzdő párok esetében is.

A Creighton Model módszer tanfolyamon a nők megtanulják, hogy milyen biológiai jeleket kell magukon megfigyelniük, hogy nyomon követhessék a ciklusaik és nőgyógyászati egészségük alakulását, ha pedig nőgyógyászati téren probléma merül fel, a NaProTechnológia nyújt nekik segítséget. Ez egy új orvosi tudományág, melynek lényege, hogy az orvos a nő egyedi ciklusával összhangban, ahhoz igazítva végez vizsgálatokat és kezeléseket, igyekezve mindent természetes módon megoldani, indokolt esetben persze modern sebészeti technikáktól és gyógyszerészeti eszközöktől sem elzárkózva. A NaProTechnológia tehát a gyógyításra helyezi a hangsúlyt. Meddőség vagy vetélés esetén a nőt és párját együtt hozza egészségesebb állapotba, az ő egészségüket akarja helyreállítani, hogy azután természetes módon foganjon meg a vágyott kisbaba. E modern, természetes családtervezési módszerek segítségével az ember megismeri a saját biológiai folyamatait és ritmusát, így összhangba tudja hozni azt a családtervezési szándékaival minden élethelyzetben.

\section{EGÉSZSÉGES ÉLETKEZDET, KORAI KÖTŐDÉS}

A szülés a szülő nő és családja életében kivételes esemény, amelynek körülményei a gyermek életkezdését és a nő anyává válásának folyamatát, lelki egészségét alapvetően befolyásolják. A szülés kimenetele, a szülést követő, kórházban töltött időszak és a kapott ellátás a szoptatás sikere, azaz a csecsemő egészsége szempontjából is meghatározó. Az apák kötődését, a család összetartozását, a nők gyermekvállalási kedvét is nagyban befolyásolja a szülés milyensége. A szülés éppúgy misztérium 
ma, mint ezer évvel ezelőtt. A háborítatlan szülés támogatói szem előtt tartják a tiszteletet a születés csodájával, az anyasággal, vagyis az Élettel szemben. A szülés bizonyítottan akkor zajlik a legnagyobb eséllyel komplikációk nélkül, ha a szülő nő biztonságban érzi magát, ehhez pedig elengedhetetlen a megfelelő körülmények megteremtése, valamint, hogy azok a személyek vegyék körül, lássák el és támogassák, akiket ismer és akikben megbízik. Fontos olyan szülészetek kialakítása, ahol tiszteletben tartják a nők, a gyermekek és a család jogait, támogatják a vajúdás és a szülés természetes élettani folyamatát.

Az édesanya és a kisbaba elválaszthatatlan egységet alkot egymással, érdekeik nem választhatók szét, nem lehet őket külön kezelni. Nem választhatók el egymástól az élet első perceiben, óráiban, napjaiban sem. A korai kapcsolat támogatása alapvető fontosságú minden gyermeknél, de ennél is lényegesebb a koraszülötteknél, a császármetszéssel világrajötteknél és a traumatizált anyáknál. A szül(et)éssel a gyermek és az anya neuropszichológiai mechanizmusai egyaránt megváltoznak. Az anya és gyermeke közötti korai bőrkontaktus a kisbaba mellhez kúszását, mellre tapadását eredményezi, megkezdődik a szopás-szoptatás, ami elősegíti a szülővé válást, az újszülött egészséges fejlődését, adaptálódását, a természetes, egészséges bio-pszicho-szociális, spirituális folyamatok kibontakozását. Megvalósul a kolonizáció, és immunológiai, fiziológiai szempontból is az ideális kezdetet kapja meg a kisbaba. Megvalósul az egészséges életkezdethez való joga. Ez eredményezi a ragaszkodást, ami a biztonságos, szeretetteljes érzelmi kötődés alapja a családokban és a társadalom egészét is szolgálja. Az apa rendszeres, aktív részvétele a gyermek életében - legyen az fiú vagy lány - szintén előrevetíti a szociális viselkedésbeli, pszichológiai és kognitív fejlődés pozitív kimenetelét. Az anyaság és az apaság tehát nem két elválasztható, jól meghatározható pszichológiai minőséget jelent, de nem is azonos vagy felcserélhető: átfedik és kiegészítik egymást.

\section{TAPASZTALATAINK ÉS ÜZENETÜNK}

A Családok Évében Szolnokon, Miskolcon, Egerben, Békéscsabán és Budapesten tartott konferenciánk mindegyikén nagy érdeklődést tapasztaltunk. Ismét érzékeltük, hogy a szakemberek, szülők, védőnők, pedagógusok látják a hiányt, azt, hogy nem esik elég szó családtervezési kérdésekről és nincs kontextusba helyezve ez a témakör a fiatalok életében és az oktatásban sem. A konferenciasorozattal összességében azt akartuk üzenni a világnak: jó lenne, ha a gyermek jövetele valóban áldás és öröm lenne az anyának, az apának és a társadalomnak egyaránt. Ahhoz viszont, hogy ez valóban így legyen, az egyénnek, a kisebb és nagyobb közösségnek egyaránt tennie kell. Ebből igyekszünk mi is részt vállalni és erre igyekeztünk rámutatni szakértő munkatársaink segítségével a rendezvényeinken.

\section{KÖSZÖNETNYILVÁNITTÁS}

Az ERGO - Európai Regionális Szervezet köszönetet mond az Emberi Erőforrások Minisztériumának, az Emberi Erőforrás Támogatáskezelőnek, a Miniszterelnökség Nemzetpolitikai Államtitkárságának és a Bethlen Gábor Alapnak a programok megvalósításához nyújtott támogatásért.

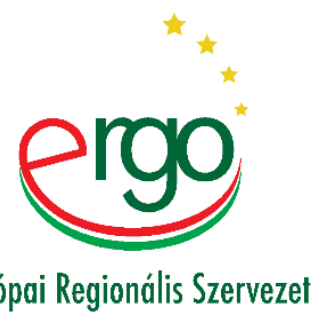

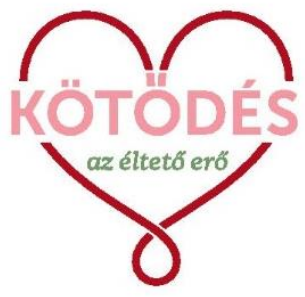

